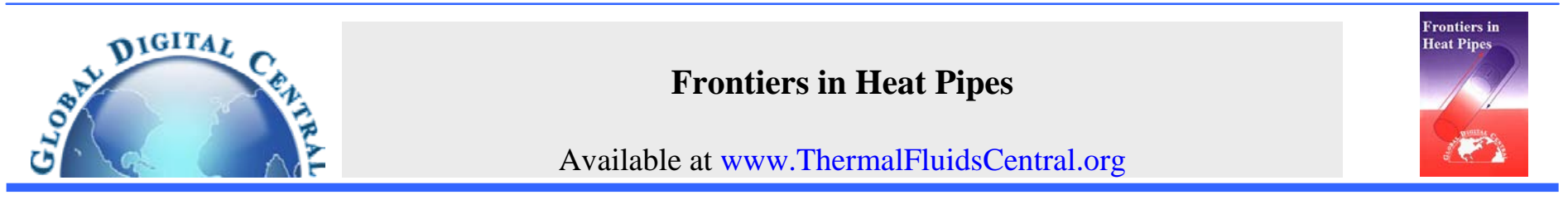

\title{
PREVENTION POSSIBILITY OF NUCLEAR POWER REACTOR MELTDOWN BY USE OF HEAT PIPES FOR PASSIVE COOLING OF SPENT FUEL
}

\author{
Masataka Mochizuki ${ }^{*}$ Thang Nguyen, Koichi Mashiko, Yuji Saito, Randeep Singh, Tien Nguyen, Vijit Wuttijumnong
}

Fujkura Ltd. 1-5-1, Kiba, Koto-Ku, Tokyo 135-8512, Japan

\begin{abstract}
In Japan, following a major earthquake, a 15-metre tsunami disabled the power supply and cooling of three Fukushima Daiichi reactors, causing a nuclear accident on 11 March 2011. All three cores largely melted in the first three days. The accident was rated 7 on the INES (International Nuclear Event Scale) scale, due to high radioactive releases in the first few days. After two weeks the three reactors (units 1-3) were stable with water addition but no proper heat sink for removal of decay heat from fuel. By July they were being cooled with recycled water from the new treatment plant, and reactor temperatures had fallen to below $80^{\circ} \mathrm{C}$ at the end of October, and official 'cold shutdown condition' was announced in mid December. In this paper, the nuclear power plant No. 4 at Fukushima was chosen for the analysis - thermal power 2,381 MW; electrical power $784 \mathrm{MW}$; 658 spent fuel bundles (39,456 spent fuel rods); spent fuel water pool volume 1,400 tonnes. Detail analysis of various heat pipe design cases to determine the best design concept in terms of cooling power, construction and cost are presented. The best design when considering thermal safety margin and cost is the heat pipe cooling $0.9 \mathrm{MW}$; 1,662 heat pipe modules; water temperature will reach to peak $68^{\circ} \mathrm{C}$ after 75 hours, and will be saturated at $50{ }^{\circ} \mathrm{C}$ after 2,000 hours. The estimated cost for complete heat pipe cooling system is about 2.16 Millions USD.
\end{abstract}

Keywords: Boiling water reactor, Pressurized water reactor, Fast breeder reactor, Nuclear power, Spent fuel, Heat pipe, Loop heat pipe.

\section{INTRODUCTION}

\subsection{What Happened at Fukushima Nuclear Reactors?}

The Great East Japan Earthquake of magnitude 9.0 on 11 March 2011 did considerable damage in the region, and the large tsunami it created caused very much more. The earthquake was centered $130 \mathrm{~km}$ offshore the city of Sendai in Miyagi prefecture on the eastern cost of Honshu Island (the main part of Japan), and was a rare and complex double quake giving a severe duration of about 3 minutes. Japan moved a few meters east and the local coastline subsided half a meter. The tsunami inundated about $560 \mathrm{sq} \mathrm{km}$ and resulted in a human death toll of over 19,000 and much damage to coastal ports and towns with over a million buildings destroyed or partly collapsed.

Eleven reactors at four nuclear power plants in the region were operating at the time and all shut down automatically when the quake hit. Subsequent inspection showed no significant damage to any from the earthquake. The reactors proved robust seismically, but vulnerable to the tsunami. Power, from grid or backup generators, was available to run the Residual Heat Removal (RHR) system cooling pumps at eight of the eleven units, and despite some problems they achieved 'cold shutdown' within about four days. The other three at Fukushima Daiichi lost power almost an hour after the quake, when the entire site was flooded by the 15-metre tsunami. This disabled 12 of 13 back-up generators on site and also the heat exchangers for dumping reactor waste heat and decay heat to the sea. The three units lost the ability to maintain proper reactor cooling and water circulation functions. Electrical switchgear was also disabled. Thereafter, many weeks of focused work centered on restoring heat removal from the reactors and coping with overheated spent fuel ponds.

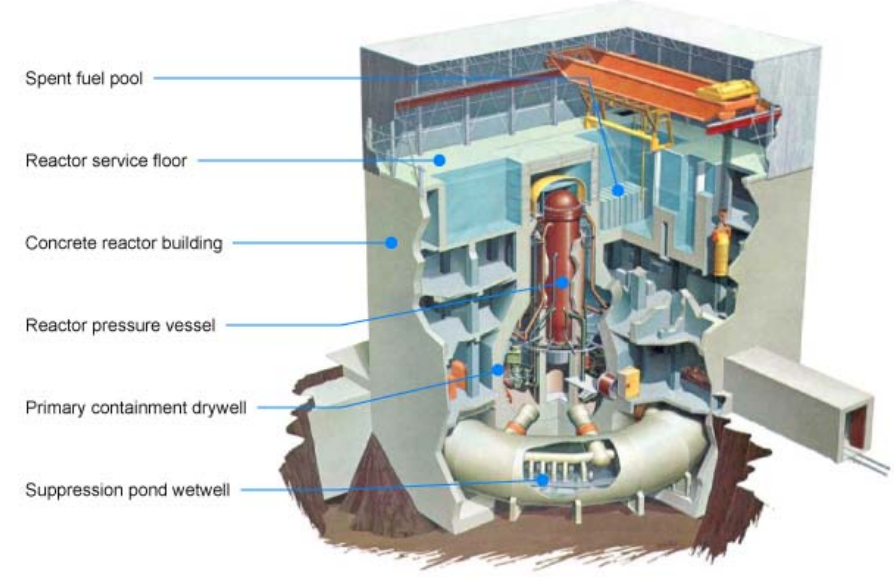

Fig. 1 Boiling water reactor (BWR) Mark I

The Fukushima Daiichi reactors are GE boiling water reactors (BWR) of an early (1960s) design supplied by GE, Toshiba and Hitachi, with what is known as a Mark I containment as shown in Fig. 1. Reactors 1-3 came into commercial operation 1971-75. Reactor power is 460 MWe for unit 1, 784 MWe for units 2-5, and 1100 MWe for unit 6.

It appears that no serious damage was done to the reactors by the earthquake, and the operating units 1-3 were automatically shut down in response to it, as designed. At the same time all six external power supply sources were lost due to earthquake damage, so the emergency diesel generators located in the basements of the turbine buildings started up. Initially cooling would have been maintained

\footnotetext{
*Corresponding author. Email: mmotizuk@fujikura.co.jp
} 
through the main steam circuit bypassing the turbine and going through the condensers. Then, 41 minutes later the first tsunami wave hit, followed by a second 8 minutes later. These waves submerged and damaged the seawater pumps for both the main condenser circuits and the auxiliary cooling circuits, notably the Residual Heat Removal (RHR) cooling system. They also drowned the diesel generators and inundated the electrical switchgear and batteries, all located in the basements of the turbine buildings, therefore, there was a station blackout, and the reactors were isolated from their ultimate heat sink. All this put those reactors 1-3 in a dire situation and led the authorities to order, and subsequently extend, an evacuation while engineers worked to restore power and cooling. The 125-volt DC batteries for units 1 \& 2 were flooded and failed, leaving them without instrumentation, control or lighting. Figure 2 shows a schematic of water level at nuclear reactor 1-4 site. It showed that the site was designed for expected tsunami level of only $5.7 \mathrm{~m}$, while the actual tsunami was about $15 \mathrm{~m}$.

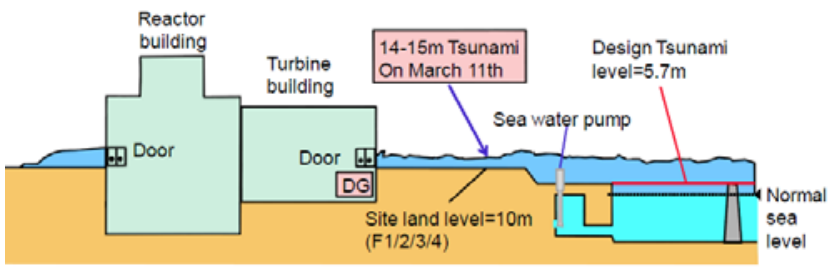

Fig. 2 Schematic of water level at nuclear reactor 1-4 site

When the power failed, at about one hour after shutdown of the fission reactions, the reactor cores would still be producing about 1.5\% of their nominal thermal power, from fission product decay which are about $22 \mathrm{MW}$ in unit 1 and $33 \mathrm{MW}$ in units $2 \& 3$. Without heat removal by circulation to an outside heat exchanger, this produced a lot of steam in the reactor pressure vessels housing the cores, and this was released into the dry primary containment (PCV) through safety valves. Later this was accompanied by hydrogen, produced by the interaction of the fuel's very hot zirconium cladding with steam after the water level dropped. As pressure started to rise here, the steam was directed into the suppression chamber under the reactor, within the containment, but the internal temperature and pressure nevertheless rose quite rapidly. Water injection commenced, using the various systems provide for this and finally the Emergency Core Cooling System (ECCS). These systems progressively failed over three days, so water injection to the reactor pressure vessel (RPV) was with fire pumps, but this required the internal pressures to be relieved initially by venting into the suppression chamber/ wet well.

Inside unit 1, it is understood that the water level dropped to the top of the fuel about three hours after the scram and the bottom of the fuel 1.5 hours later. The temperature of the exposed fuel rose to some $2800^{\circ} \mathrm{C}$ so that the central part started to melt after a few hours and by 16 hours after the scram most of it had fallen into the water at the bottom of the RPV. There was a hydrogen explosion on the service floor of the building above unit 1 reactor containment, blowing off the roof and cladding on the top part of the building, after the hydrogen mixed with air and ignited due to the oxidation of the zirconium cladding at high temperatures in the presence of steam produces hydrogen exothermically, with this exacerbating the fuel decay heat problem. In unit 1 most of the core as corium comprised of melted fuel and control rods, was assumed to be in the bottom of the RPV, but later it appeared that it had mostly gone through the bottom of the RPV and eroded about $65 \mathrm{~cm}$ into the drywell concrete below in which is $2.6 \mathrm{~m}$ thick. This reduced the intensity of the heat and enabled the mass to solidify. Figure 3 shows the picture of nuclear reactor site damage for unit 1, 2, 3 and 4 before (picture above) and 13 days (picture below) after the accident. Tepco has said that the three reactors, with unit 4, are written off and will be decommissioned.
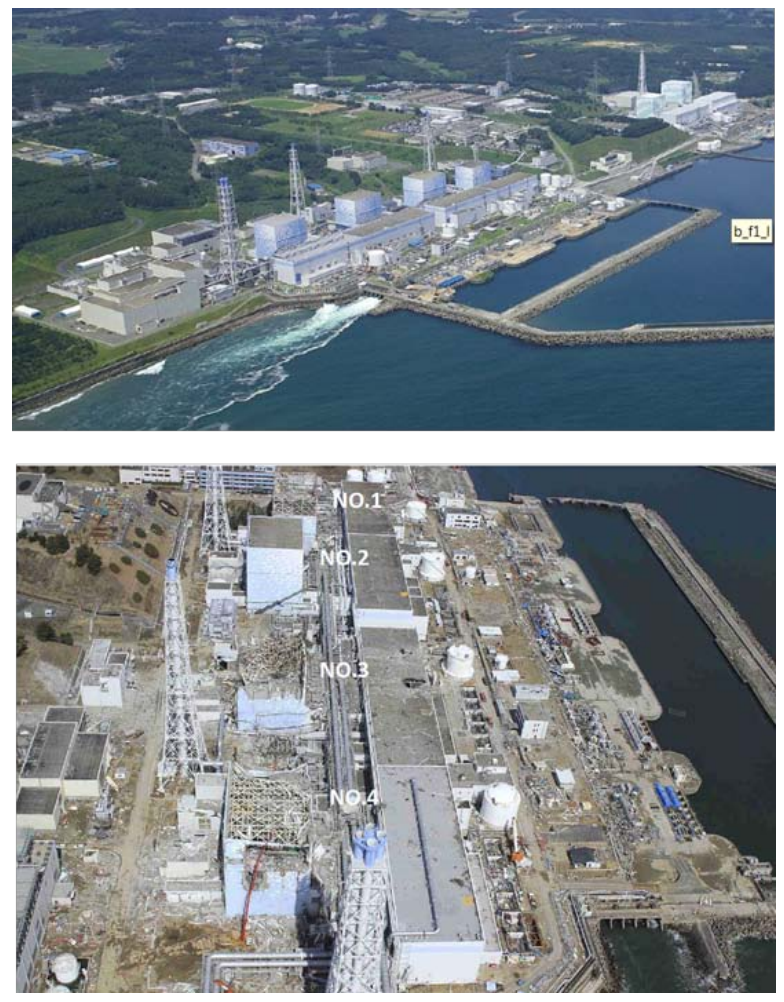

Fig. 3 Nuclear reactor 1-4 site before and after the accident

\subsection{Nuclear Reactor Introduction}

Nuclear power has the potential to support the electric energy needs of the growing population. Nuclear energy share in global electricity production is growing fast due to its high energy density, advanced reactor technology, low greenhouse gas emissions, ease of installation and plant expansion. In nuclear power plants, kinetic energy produced by the nuclear fission of the radioactive material (usually uranium-235 or plutonium-239) is converted to heat and thereby to useful electrical power. Nuclear fission provides very high density energy, for example one $\mathrm{kg}$ of U-235 can produce 3 million times of energy generated by equivalent mass of coal. Japan has total of 54 nuclear power reactors with total electric power capacity of 49 GW (30\% of country's demand) and there is proposal for 19 new reactors with total capacity of $13 \mathrm{GW}$ to be built in the near future.

Two most commonly used reactors in nuclear power plants are pressurized water reactor (PWR) and boiling water reactor (BWR). PWR pumps high pressure coolant (water) to the reactor core to extract energy from the nuclear fission reaction. The hot water is then passed through the steam generator where it heats up the secondary coolant and produce steam which is passed through turbine to generate electricity. Unlike PWR, in BWR the steam $\left(\sim 282{ }^{\circ} \mathrm{C}\right)$ is generated in the nuclear core that is directly used to drive the turbine. In case of an accident, BWR is more susceptible to radiation leak than PWR, due to direct utilization of the contaminated steam in the turbine located outside the primary containment. The BWR containment consists of drywell that houses reactor with related cooling system and wet well or suppression pool. The suppression pool contains water charge for core cooling during emergency reactor shutdown and for dumping excess heat (nuclear reaction control) during reactor operation. Figure 4 presents the schematic of the BWR based nuclear power plant, having reactor vessel with fuel and control rods assemblies, turbine and generator arrangement, sea water cooled condenser, suppression pool and, most importantly, electrically driven ECCS with pumps. Nuclear power plants normally use sea water for cooling purpose. In case of any 
malfunctioning, the nuclear reactors are automatically shut down by using control rod mechanism. After shutdown, the ECCS is required to transfer and dissipate the residual heat from the core and maintain reactor temperature within safer limits $\left(<100^{\circ} \mathrm{C}\right)$. The ECCS, which is activated after reactor shut down, typically uses diesel generators to power number of pumps for spraying high pressure water on the hot core. If the active water cooling system stops due to loss of electrical power, then the reactor internal temperature and pressure will build-up due to steam formation from accumulated residual heat causing fuel meltdown $\left(\sim 1,800{ }^{\circ} \mathrm{C}\right)$ and reactor vessel damage.

Reactor Building

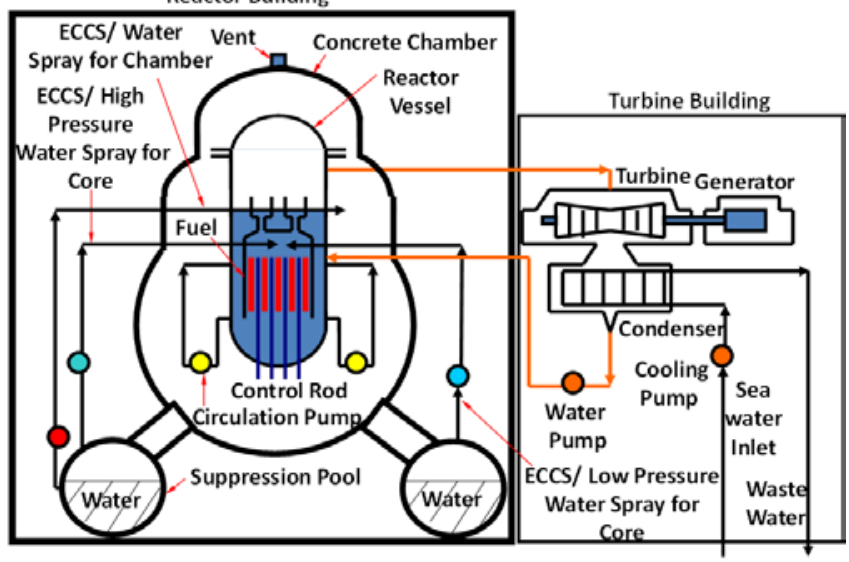

Fig. 4 Boiling water reactor with ECCS system

One of the worst nuclear accident at Fukushima nuclear power plant resulted from the failure of electric generators for ECCS that was caused by M9 earthquake and Tsunami triggered by it. The system described in Figure 4 is similar to the BWR used in Fukushima nuclear power plants. Active ECCS is not reliable due to their dependence on the electric power and therefore is prone to failure during adverse natural calamities. Mochizuki et al (2012) proposed a totally passive cooling system using heat pipe for ECCS. In this paper is a detail case study proposal of using heat pipe for cooling of spent fuel as shown in Fig. 5.

\section{DESIGN CASES STUDIES}

\subsection{Conceptual Design Proposal of Cooling System for Spent Fuel Using Thermal Diode Heat Pipes}

Table 1 shows the outline specification of nuclear power reactors in Fukushima facility in Japan. The nuclear power reactor No. 1 is the power plant that was damaged and caused nuclear leakage in 2011 natural disaster as mentioned in the introduction section. In this study, the nuclear reactor No. 4 has been chosen for detail thermal analysis and design proposal of cooling system for spent fuel using heat pipe. An example of the structure of the spent fuel unit is shown in Fig. 6.

The thermal specification for the nuclear power reactor No. 4 for the analysis in this paper is assumed as below:

- Thermal power: 2,381 MW.

- Electrical power: $784 \mathrm{MW}$.

- Fuel quantity: 34,956 units.

- Time of reactor shutdown from startup 1.5 years.

- Fuels are remained in the reactor for about 1 month after shutdown, the fuels are then transferred to the water cool pool spent fuel.

Figure 7 (a) and (b) shows a front and plan view respectively of a schematic design concept of a cooling system for spent fuel using thermal diode heat pipes. The term thermal diode heat pipe means the heat flow only in one direction from the evaporator in the lower section, to the condenser in the upper section. The working liquid inside the heat pipe, after condensed in the condenser, is returned to the evaporator by gravity. The heat pipe evaporator section is submersed in the water pool of spent fuel. The spent fuel bundles of height approximate $4.5 \mathrm{~m}$ totally submersed in the deep water pool of $10 \mathrm{~m}$ in height and contained about 1400 tons of water. The heat pipe condenser length $\mathrm{OF}$ about $4 \mathrm{~m}$ is exposed to ambient environment and it is cooled by natural air convection.

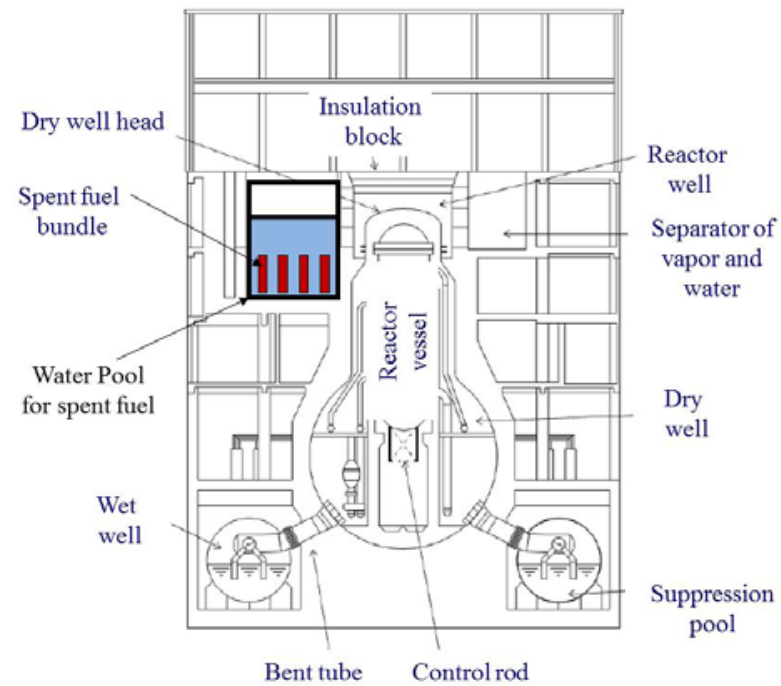

Fig. 5 Boiling water reactor with spent fuel cool pool

Table 1. Nuclear power reactor in Fukushima

\begin{tabular}{|c|c|c|c|c|c|}
\hline & N0.1 & N0.2 & N0.3 & N0.4 & N0.5 \\
\hline Electric-Power (MW) & 460 & \multicolumn{4}{|c|}{784} \\
\hline Thermal Power (MW) & 1,380 & \multicolumn{4}{|c|}{2,381} \\
\hline Construction & Sept, 1967 & May, 1969 & Oct, 1970 & Sept, 1972 & Dec, 1971 \\
\hline Commercial Operation & March, 1971 & July, 1974 & March, 1976 & Oct, 1978 & April, 1978 \\
\hline Type of Nuclear Reactor & & \multicolumn{4}{|c|}{ Boiling Water Reactor(BWR) } \\
\hline Type of Reactor & & \multicolumn{4}{|c|}{ Mark-I } \\
\hline Contractor & GE & GE+Toshiba & Toshiba & Hitachi & Toshiba \\
\hline Number of Fuel Bundle & 400 & \multicolumn{4}{|c|}{548} \\
\hline Length of Fuel Core(m) & 4.35 & \multicolumn{4}{|c|}{4.47} \\
\hline Number of Control Rod & 97 & \multicolumn{4}{|c|}{137} \\
\hline Reactor Vessel & & & & & \\
\hline $\mathrm{ID}(\mathrm{m})$ & 4.8 & \multicolumn{4}{|c|}{5.6} \\
\hline Height(m) & 20 & \multicolumn{4}{|c|}{22} \\
\hline Weight(Ton) & 440 & \multicolumn{4}{|c|}{500} \\
\hline \multicolumn{6}{|l|}{ Concrete Chamber } \\
\hline Height(m) & 32 & & 33 & & 34 \\
\hline$O D$ of $T o p(m)$ & 10 & \multicolumn{4}{|c|}{11} \\
\hline OD of Bottom(m) & 18 & \multicolumn{4}{|c|}{20} \\
\hline $\begin{array}{c}\text { Water Volume of } \\
\text { Sunoression Pool(Ton) }\end{array}$ & 1,750 & \multicolumn{4}{|c|}{2,980} \\
\hline \multicolumn{6}{|l|}{ Turbine } \\
\hline Rotation(rpm) & & \multicolumn{4}{|c|}{1,500} \\
\hline Inlet Temp. of vapor $\left({ }^{\circ} \mathrm{C}\right)$ & & \multirow{2}{*}{\multicolumn{4}{|c|}{$\frac{282}{66: 8}$}} \\
\hline Vapor Pressure $\left(\mathrm{Kg} / \mathrm{cm}^{2} . \mathrm{G}\right.$ & & \multirow{2}{*}{\multicolumn{3}{|c|}{$66 ; 8$}} & \\
\hline & & \multirow{2}{*}{\multicolumn{4}{|c|}{ Oxide Uranium }} \\
\hline Type of Fuel & & & & & \\
\hline Weight(Ton) & 69 & \multicolumn{4}{|c|}{94} \\
\hline
\end{tabular}

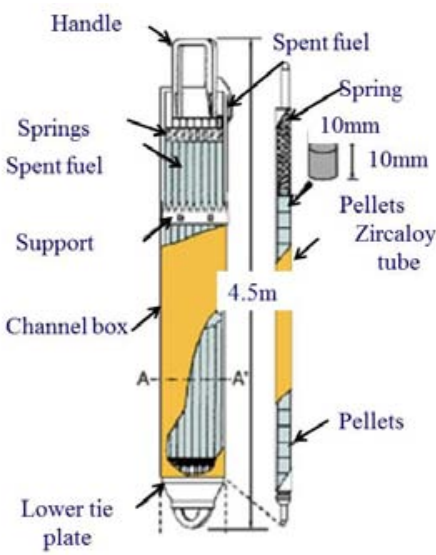

Fig. 6 Outline structure of the spent fuel 
Figure 8 shows a concept and picture of the corrugated heat pipe. The corrugated heat pipe is chosen due to design robust and flexibility for integration into the system. The corrugated heat pipe is commercially available and had been using in snow melting of roads and pedestrian walkways in Japan. The heat pipe is made of stainless steel and working liquid is ammonium. The lengths of the evaporator and the condenser are about $6 \mathrm{~m}$ and $4 \mathrm{~m}$ respectively. For enhancement of air cooling, aluminum fins are mechanically insert in the condenser section.

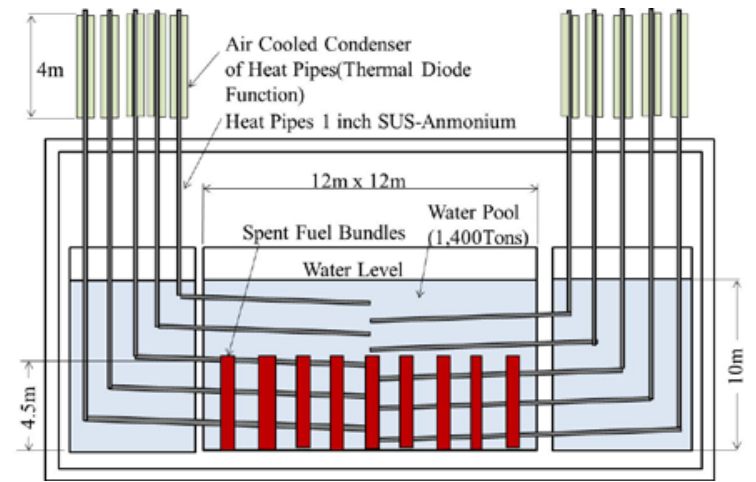

(a)

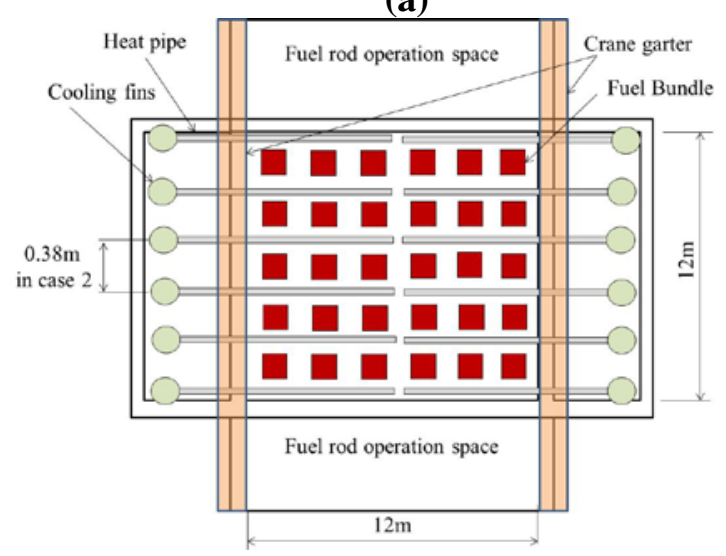

(b)

Fig. 7 Conceptual design of cooling system for spent fuel using thermal diode heat pipes (a) Front view; (b) Plan view

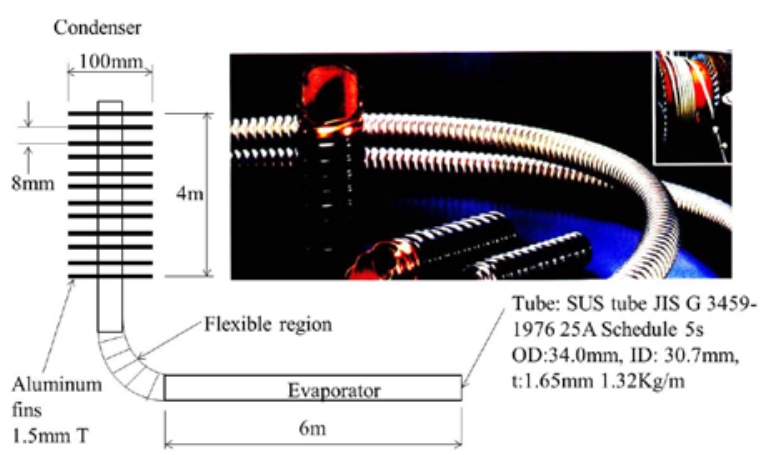

Fig. 8 Corrugated heat pipe

\subsection{Thermal Design Analysis of Heat Pipes}

The calculations are based on the reference (Mochizuki et al, 2012).

\subsubsection{Heat Pipe Fin Air Side Heat Transfer Calculation}

Table 2 shows an example of calculation of fin tube design. In brief, the calculation shows that with the air flow velocity of $1 \mathrm{~m} / \mathrm{s}$ gives a reasonable fin to air heat transfer coefficient of about $12 \mathrm{~W} / \mathrm{m} 2 \mathrm{~K}$; air pressure drop $1.22 \mathrm{mmHg}$ for the fin geometry of OD $0.1 \mathrm{~m}$, fin pitch $0.008 \mathrm{~m}$, fin thickness $0.0015 \mathrm{~m}$, and the fin efficiency 0.97 .

Table 2. Heat Pipe Fin Air Side Heat Transfer Calculations

\begin{tabular}{|c|c|c|c|}
\hline Property \& Value & Symbol & Value & Unit \\
\hline Thermal Conductivity of Air & $\lambda a$ & 0.026 & $\mathrm{~W} / \mathrm{m} .{ }^{\circ} \mathrm{C}$ \\
\hline OD of Tube & do & 0.034 & m \\
\hline Viscosity of Air & $\mu \mathrm{a}$ & 1.91.E-06 & $\mathrm{kg} \cdot \mathrm{s} / \mathrm{m}^{2}$ \\
\hline$O D$ of fin & Do-fin & 0.10 & m \\
\hline ID of fin & Di-fin & 0.034 & $\mathrm{~m}$ \\
\hline Fin Pitch & $\mathrm{Pf}$ & 0.008 & m \\
\hline Fin thickness & tf & 0.0015 & m \\
\hline Fin heat transfer area per $1 \mathrm{~m}$ & Ao & 1.74 & $\mathrm{~m}^{2} / \mathrm{m}$ \\
\hline Bare tube heat transfer area per $1 \mathrm{~m}$ & $\mathrm{AO}^{*}$ & 0.0867 & $\mathrm{~m}^{2} / \mathrm{m}$ \\
\hline Specific Heat of Air & Cpa & 1.005 & $\mathrm{~kJ} / \mathrm{kg} \cdot{ }^{\circ} \mathrm{C}$ \\
\hline Cooling air velocity & Vair & 1 & $\mathrm{~m} / \mathrm{s}$ \\
\hline Density of Air & ya & 1.129 & $\mathrm{~kg} / \mathrm{m}^{3}$ \\
\hline Max. Flow Rate of Air & Gmax & 4,064 & $\mathrm{~kg} / \mathrm{m}^{2} \cdot \mathrm{hr}$ \\
\hline Heat Transfer Coefficient of Fin Tubes & aair & 12 & $\mathrm{~W} / \mathrm{m}^{2} \cdot \mathrm{K}$ \\
\hline Pitch of tube on $\mathrm{X}$ direction & S1 & 0.12 & m \\
\hline Pitch of tube on $Y$ direction & s2 & 0.12 & m \\
\hline f factor & $f$ & 1.06 & Non \\
\hline Number of tube rows & $\mathrm{J}$ & 20 & Non \\
\hline Coefficient of Gravity & $g c$ & 1.27.E+08 & $\mathrm{kg} \cdot \mathrm{m} / \mathrm{hr} r^{2} \cdot \mathrm{kg}$ \\
\hline Pressure Drop of Air & $\Delta$ air & 1.217 & mmAq \\
\hline Thermal conductivity of fin (Al) & $\lambda f e$ & 160 & $\mathrm{~W} / \mathrm{m} \cdot{ }^{\circ} \mathrm{C}$ \\
\hline Half of Fin thickness & $\mathrm{yb}$ & 0.00075 & m \\
\hline Fin height & w & 0.033 & m \\
\hline Coefficient of fins & $x_{f}$ & 0.29 & Non \\
\hline $1 / 2 \times$ Fin OD & $\mathrm{xe}$ & 0.05 & m \\
\hline $1 / 2 \times$ Tube $O D$ & $\mathrm{xb}$ & 0.017 & $\mathrm{~m}$ \\
\hline Coefficient of fin and tube height & $z$ & 2.94 & Non \\
\hline Fin efficiency & $\varphi f$ & 0.97 & Non \\
\hline
\end{tabular}

\subsubsection{Heat Pipe Water Side Heat Transfer Calculation}

Table 3 shows the calculation of heat transfer on the water side, assuming water temperature and heat pipe temperature of $50{ }^{\circ} \mathrm{C}$ and $40{ }^{\circ} \mathrm{C}$ respectively. With the heat pipes placed horizontal and natural convection heat transfer, the calculation results showed that the average heat transfer coefficient between heat pipe and cooling water is approximate $670 \mathrm{~W} / \mathrm{m}^{2} \mathrm{~K}$.

\subsubsection{Heat Pipe Evaporation Heat Transfer Calculation}

The evaporation heat transfer coefficient inside heat pipe is calculated using Imura correlation (Mochizuki et al, 2012). The boundary conditions and assumptions are given in the below. The evaporation heat transfer coefficient is calculated about 1,281 $\mathrm{W} / \mathrm{m}^{2} . \mathrm{K}$ as shown in Table 4.

- Working fluid ammonia at $40^{\circ} \mathrm{C}$ operating temperature.

- Heat pipe inclination 2 degrees.

- Evaporator length $6 \mathrm{~m}$.

- Heat transfer rate of heat pipe $0.257 \mathrm{~kW}$.

- Heat flux at evaporator $445 \mathrm{~W} / \mathrm{m}^{2}$.

- Tube: SUS JIS G3459-1976, 25A, Schedule 5s, OD 34mm. ID $30.7 \mathrm{~mm}, \mathrm{t} 1.65 \mathrm{~mm}, 1.32 \mathrm{~kg} / \mathrm{m}$.

Table 3. Water Side Heat Transfer Calculations

\begin{tabular}{|lccc}
\hline Properties \& Values & Symbol & Value & Unit \\
\hline Prandtl number & $\mathrm{Pr}$ & 3.57 & $\mathrm{Non}$ \\
Gravity & $\mathrm{g}$ & 9.8 & $\mathrm{~m} / \mathrm{s}^{2}$ \\
Expansion coeeficient of water & $\beta$ & 0.00045 & $1 /{ }^{\circ} \mathrm{C}$ \\
OD of tube & $\mathrm{do}$ & 0.034 & $\mathrm{~m}$ \\
Water temp. & $\mathrm{tw}$ & 50 & ${ }^{\circ} \mathrm{C}$ \\
Tube temp. & $\mathrm{t}$ & 40 & ${ }^{\circ} \mathrm{C}$ \\
Dynamic viscosity of water & $\mathrm{vw}$ & $5.55 . \mathrm{E}-07$ & $\mathrm{~m}{ }^{2} / \mathrm{s}$ \\
Grasphof number & $\mathrm{Gr}$ & $5,627,161$ & \\
Average Nusselt number & $\mathrm{Num}$ & 35.483 & \\
Thermal conductivity of water & $\lambda w$ & 0.6 & $\mathrm{~W} / \mathrm{m}^{2} .{ }^{\circ} \mathrm{C}$ \\
Average heat transfer coefficient & $\mathrm{aw}$ & 670 & $\mathrm{~W} / \mathrm{m}^{2} .{ }^{\circ} \mathrm{C}$ \\
\hline
\end{tabular}


Table 4. Heat pipe Evaporator Heat Transfer Calculations

\begin{tabular}{lccc}
\hline Property \& Value & Symbol & Value & Unit \\
\hline ID of tube & $\mathrm{di}$ & 0.0307 & $\mathrm{~m}$ \\
Density of liquid & $\rho \mathrm{l}$ & 568.4 & $\mathrm{~kg} / \mathrm{m}^{3}$ \\
Density of vapor & $\rho \mathrm{N}$ & 14.48 & $\mathrm{~kg} / \mathrm{m}^{3}$ \\
Thermal conductivity liquid & $\mathrm{N}$ & 0.433 & $\mathrm{~W} / \mathrm{m} .{ }^{\circ} \mathrm{C}$ \\
Specific heat of liquid & $\mathrm{Cpl}$ & 5020 & $\mathrm{~J} / \mathrm{kg} .{ }^{\circ} \mathrm{C}$ \\
Gravity & $\mathrm{g}$ & 9.81 & $\mathrm{~m} / \mathrm{s}^{2}$ \\
Heat flux at evaporator & $\mathrm{qe}$ & 445 & $\mathrm{~W} / \mathrm{m}^{2}$ \\
Latent heat of NH3 & $\mathrm{L}$ & $1,066,000$ & $\mathrm{~J} / \mathrm{kg}$ \\
Viscosity of NH3 & $\mu \mathrm{l}$ & 0.000114 & $\mathrm{~Pa} . \mathrm{S}$ \\
X factor & $\mathrm{X}$ & 1,669 & $\mathrm{Non}$ \\
Inside pressure & Pin & $1.87 . \mathrm{E}+06$ & $\mathrm{~Pa}$ \\
Ambient pressure & Po & $1.01 . \mathrm{E}+05$ & $\mathrm{~Pa}$ \\
Boiling heat transfer coefficient & $\alpha \mathrm{e}$ & 1,281 & $\mathrm{~W} / \mathrm{m}^{2} .{ }^{\circ} \mathrm{C}$ \\
\hline
\end{tabular}

\subsubsection{Heat Pipe Condensation Heat Transfer Calculation}

The condensation heat transfer coefficient is calculated about 8857 $\mathrm{W} / \mathrm{m}^{2} . \mathrm{K}$ as shown in Table 5 .

Table 5. Heat pipe Condensation Heat Transfer Calculations

\begin{tabular}{|lccc|}
\hline Properties \& Values & Symbol & Value & Unit \\
\hline Density of liquid & $\mathrm{\rho l}$ & 568.4 & $\mathrm{~kg} / \mathrm{m}^{3}$ \\
Thermal conductivity liquid & $\mathrm{Nl}$ & 0.433 & $\mathrm{~W} / \mathrm{m}^{\circ} \mathrm{C}$ \\
Gravity & $\mathrm{g}$ & 9.81 & $\mathrm{~m} / \mathrm{s}^{2}$ \\
Inside diameter of Tube & di & 0.0307 & $\mathrm{~m}$ \\
Length of condenser & $\mathrm{Lc}$ & 4 & $\mathrm{~m}$ \\
Heat transfer area of condenser & $\mathrm{AC}$ & 0.386 & $\mathrm{~m}^{2}$ \\
Heat transfer rate of heat pipe & $\mathrm{Qhp}$ & 0.257 & $\mathrm{~kW}$ \\
Heat flux at condenser & $\mathrm{qc}$ & 666.5 & $\mathrm{~W} / \mathrm{m}^{2}$ \\
Latent heat of NH3 & $\mathrm{L}$ & $1,066,000$ & $\mathrm{~J} / \mathrm{kg}^{\circ}$ \\
Viscosity of NH3 & $\mu l$ & 0.000114 & $\mathrm{~Pa} . \mathrm{S}$ \\
Condensation heat transfer coefficient & ac & 8,857 & $\mathrm{~W} / \mathrm{m}^{2} .{ }^{\circ} \mathrm{C}$ \\
\hline
\end{tabular}

\subsubsection{Summary of Overall Heat Pipe Heat Transfer Calculation}

Table 6 shows a summary of overall heat pipe heat exchanger thermal performance.

Table 6. Summary of Overall Heat Pipe Heat Transfer Calculations

\begin{tabular}{lccc}
\hline Properties \& Values & Symbol & Value & Unit \\
\hline Heat transfer coefficient at evaporator & ae & 1,281 & $\mathrm{~W} / \mathrm{m}^{2} .{ }^{\circ} \mathrm{C}$ \\
ID of Tube & di & 0.0307 & $\mathrm{~m}$ \\
Length of evaporator & Le & 6 & $\mathrm{~m}$ \\
Heat transfer area at evaporator & Ae & 0.578 & $\mathrm{~m} 2$ \\
Heat transfer coefficient at water side & aw & 670 & $\mathrm{~W} / \mathrm{m}^{2} .{ }^{\circ} \mathrm{C}$ \\
OD of Tube & do & 0.034 & $\mathrm{~m}$ \\
Heat transfer area at water side & Aw & 0.641 & $\mathrm{~m}^{2}$ \\
Heat transfer coefficient at condenser & ac & 8.857 & $\mathrm{~W} / \mathrm{m}^{2} .{ }^{\circ} \mathrm{C}$ \\
Length of condenser & Lc & 4 & $\mathrm{~m}$ \\
Heat transfer area of inside condenser & Ac & 0.386 & $\mathrm{~m}^{2}$ \\
Heat transfer coefficient at fin tubes & aa & 10.28 & $\mathrm{~W} / \mathrm{m}^{2}{ }^{\circ} \mathrm{C}$ \\
OD of fin & Do-fin & 0.1 & $\mathrm{~m}$ \\
ID of fin & Di-fin & 0.034 & $\mathrm{~m}$ \\
Fin pitch & Pf & 0.008 & $\mathrm{~m}$ \\
Fin thickness & tf & 0.0015 & $\mathrm{~m}$ \\
Fin heat transfer area per 1m & Ao & 1.736 & $\mathrm{~m}^{2} / \mathrm{m}$ \\
Bare tube heat transfer area per 1m & Ao* & 0.087 & $\mathrm{~m}^{2} / \mathrm{m}$ \\
Heat transfer area at Condenser & Afin & 7.290 & $\mathrm{~m}^{2}$ \\
Fin efficiency & $\varphi f$ & 0.97 & $\mathrm{Non}$ \\
Total thermal resistance & Rhp & 0.0177 & ${ }^{\circ} \mathrm{C} / \mathrm{W}$ \\
\hline
\end{tabular}

\subsection{Design Cases Evaluation}

\subsubsection{Nuclear Decay Heat - No cooling case}

The nuclear decay heat is calculated using equation (1) (Glasstone \& Sesonske, 1967), where:

- P (t): Decay heat as function of time [W]
- $\mathrm{P}_{\mathrm{o}}$ : Normal thermal power before shutdown [W]

- t: Time since reactor shutdown [s]

- $\mathrm{t}_{\mathrm{s}}$ : Time of reactor shutdown from start-up [s]

$$
\frac{P(t)}{P_{0}}=0.066 \times\left[t^{-0.2}-\left(t_{s}+t\right)^{-0.2}\right]
$$

Figure 9 shows the nuclear decay heat and temperature rise of cooling water with time in case of no cooling, in which the water temperature increased over $100{ }^{\circ} \mathrm{C}$ just in one day. The boundary conditions and assumptions are stated in the below:

- Water cooling volume 1,400 tons at initial temperature $30^{\circ} \mathrm{C}$.

- Time of reactor shutdown from start-up: 1.5 years.

- Fuels are remained in the reactor for 1 month, and after transferred to water cooling pool.

- Decay heat at start of cooling = 3.6 MW

- Heat dissipation at water surface is neglected.

- Ambient temperature $30^{\circ} \mathrm{C}$.

Figure 10 shows the cooling water temperature rise with time for heat pipe design case 1 . The cooling water temperature increased to $100{ }^{\circ} \mathrm{C}$ in about 85 hours, then saturated to $70{ }^{\circ} \mathrm{C}$ after 2,000 hours. This case 1 seems small cooling capacity. Figure 11 shows the cooling water temperature rise with time for heat pipe design case 2 . The cooling water temperature increased to $68^{\circ} \mathrm{C}$ in about 75 hours, then saturated to $50{ }^{\circ} \mathrm{C}$ after 2,000 hours. This case 2 seems reasonable cooling capacity. Figure 12 shows the cooling water temperature rise with time for heat pipe design case 3 . The cooling water temperature increased to $49{ }^{\circ} \mathrm{C}$ in about 40 hours, then saturated to $40{ }^{\circ} \mathrm{C}$ after 2,000 hours. This case 3 seems also reasonable cooling capacity. Figure 13 shows the cooling water temperature rise with time for heat pipe design case 4 . The cooling water temperature increased to $39{ }^{\circ} \mathrm{C}$ in about 21 hours, then saturated to $35{ }^{\circ} \mathrm{C}$ after 1,500 hours. This case 4 seems is over design cooling capacity.

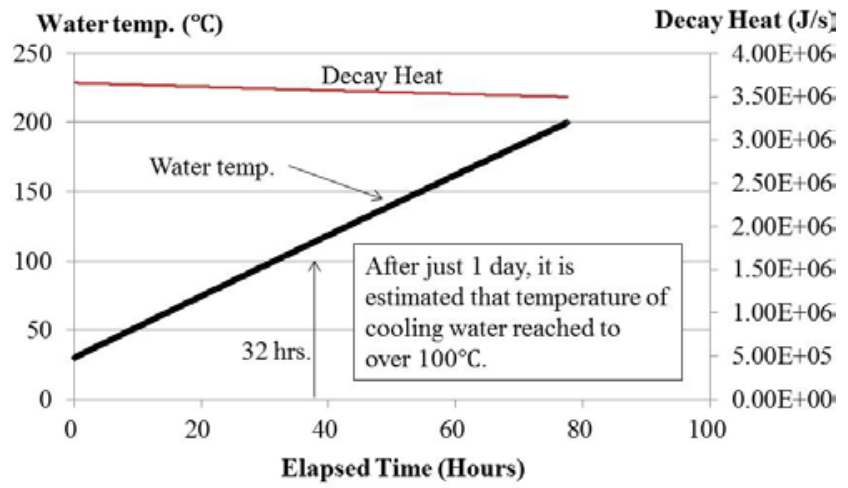

Fig. 9 Nuclear decay heat

2.3.2 Nuclear Decay Heat - Heat pipe cooling cases

Table 7 shows 4 cases of heat pipe design for evaluation of cooling performance and cost.

Table 7. Heat Pipe Design Cases

\begin{tabular}{|l|c|c|c}
\hline & $\begin{array}{c}\text { Ratio of heat pipe } \\
\text { cooling to total } \\
\text { thermal power }\end{array}$ & $\begin{array}{c}\text { Required } \\
\text { thermal } \\
\text { resistance [Rhp] }\end{array}$ & $\begin{array}{c}\text { Quantity of } \\
\text { heat pipes } \\
\text { required }\end{array}$ \\
\hline Case 1- Qhp $=0.45 \mathrm{MW}$ & $0.019 \%$ & $2.19 \times 10^{-5}{ }^{\circ} \mathrm{C} / \mathrm{W}$ & 823 \\
\hline Case 2-Qhp $=0.9 \mathrm{MW}$ & $0.038 \%$ & $1.09 \times 10^{-5}{ }^{\circ} \mathrm{C} / \mathrm{W}$ & 1662 \\
\hline Case 3-Qhp $=1.8 \mathrm{MW}$ & $0.076 \%$ & $5.47 \times 10^{-6}{ }^{\circ} \mathrm{C} / \mathrm{W}$ & 3292 \\
\hline Case 4-Qhp $=3.6 \mathrm{MW}$ & $0.151 \%$ & $2.73 \times 10^{-6} \mathrm{\circ} / \mathrm{W}$ & 6648 \\
\hline
\end{tabular}


Water temp. $\left({ }^{\circ} \mathrm{C}\right)$

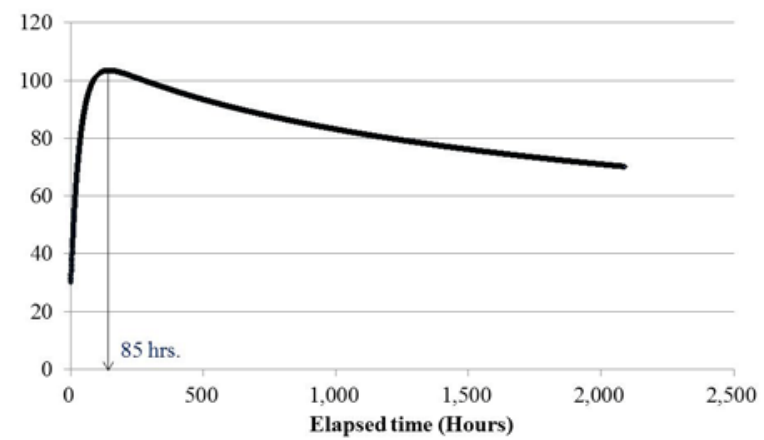

Fig. 10 Heat pipe design case 1

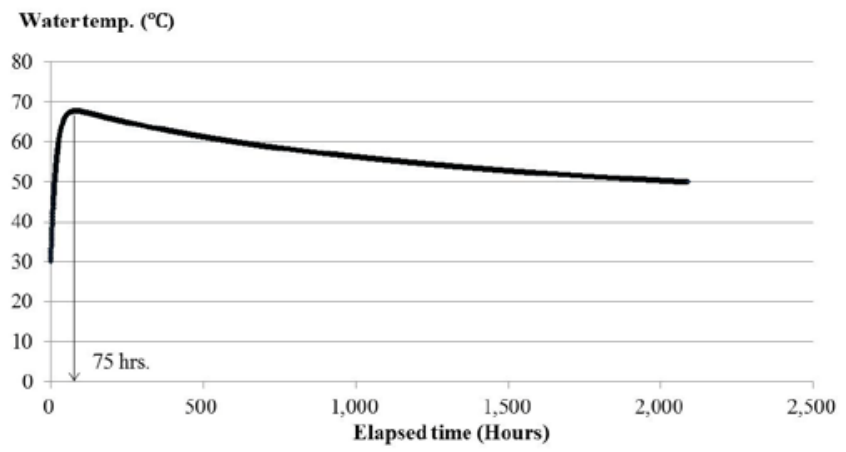

Fig. 11 Heat pipe design case 2

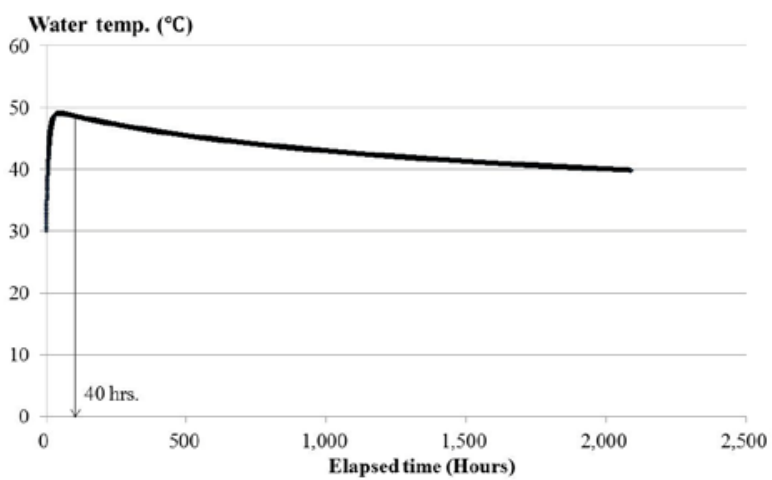

Fig. 12 Heat pipe design case 3

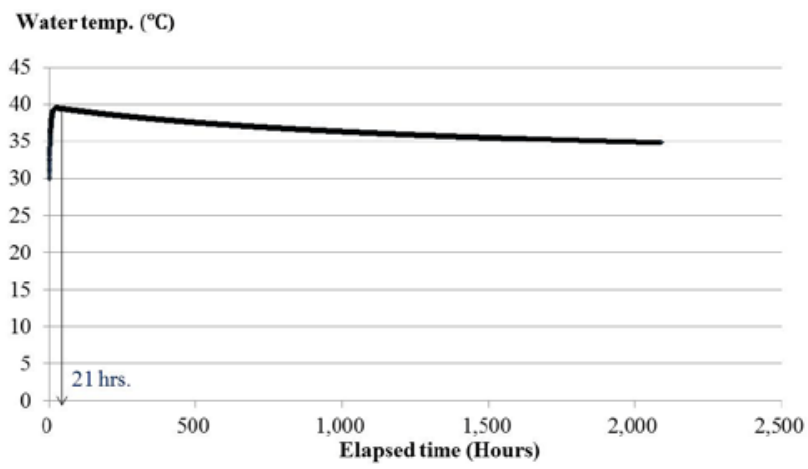

Fig. 13 Heat pipe design case

\section{SUMMARY AND CONCLUDING REMARKS}

1. The proposed heat pipe cooling system for cooling of spent fuel for Fukushima nuclear No. 4 is completely passive without any use of electrical power.

2. The general boundary conditions and assumptions for the thermal analysis are: Thermal power 2,381 MW; Electrical power 784 MW; Fuel quantity 34,956 units; Time of reactor shut down from started up 1.5 years; Fuels are remained in the reactor for about 1 month after shutdown, the fuels are then transferred to the water cool pool spent fuel; Decay heat at the start of cooling is 3.6 MW; Water volume in spent fuel pool is 1400 tons at initial temperature of $30^{\circ} \mathrm{C}$ and ambient temperature $30^{\circ} \mathrm{C}$.

3. There are 4 cases of heat pipe design presented, with thermal performance and heat transfer capability comparison from under design to over design.

4. Heat pipe is a 1 inch diameter corrugated stainless steel and working liquid is ammonium. The heat pipe condenser is $4 \mathrm{~m}$ long with $0.1 \mathrm{~m}$ diameter aluminum fins, fin pitch $0.008 \mathrm{~m}$, fin thickness $0.0015 \mathrm{~m}$, and cooling is by natural air convection. The heat pipe evaporator is $6 \mathrm{~m}$ long, horizontally placed at 2 degrees angle at the bottom of the spent fuel water cooling pool.

5. Without heat pipe cooling, the water temperature in the spent fuel pool will increased to $100{ }^{\circ} \mathrm{C}$ in 32 hours.

6. Heat pipe design case \#1: Qhp $=0.45 \mathrm{MW}$, Heat pipe quantity 823 pcs. After 85 hours, the water temperature increased to $100^{\circ} \mathrm{C}$ and it will be evaporate. This is under design cooling capacity.

7. Heat pipe design case \#2: Qhp $=0.9 \mathrm{MW}$, Heat pipe quantity 1,662 pcs. After 75 hours, the water temperature will reach to $68^{\circ} \mathrm{C}$, then saturated to $50^{\circ} \mathrm{C}$ after 2000 hours. This design is very reasonable and economical design.

8. Heat pipe design case \#3: Qhp $=1.8 \mathrm{MW}$, Heat pipe quantity 3,292 pcs. After 40 hours, the water temperature will reach to $49^{\circ} \mathrm{C}$, then saturated to $40^{\circ} \mathrm{C}$ after 2,000 hours. This design is reasonable with extra design safety.

9. Heat pipe design case \#4: $\mathrm{Qhp}=3.6 \mathrm{MW}$, Heat pipe quantity 6,648pcs. After 21 hours, water temperature will reach to $39^{\circ} \mathrm{C}$, then saturated to $35^{\circ} \mathrm{C}$ after 1500 hours. This is over design.

10. It is recommended to use design case \#2 when considering reasonable design safety margin and economical cost.

11. The cost of heat pipes for case \#2 is estimated about 1300 USD x 1666 pcs $=2.16$ Million USD.

\section{REFERENCES}

Glasstone, S., Sesonske, A., Nuclear Reactor Engineering, 2nd Ed., Van Nostrand Reinhold, 1967.

Mochizuki, M., Singh, R., Nguyen, Th., Nguyen, Ti., Mashiko, k., Saito, Y., Wuttijumnong, V., Completely Passive Heat Pipe Based Emergency Core Cooling System For Nuclear Power Reactor, 16th International Heat Pipe Conference, Lyon, France, May 20-24, 2012.

Yoshioka, R., Lino, K., Technical Report Fukushima Accident Summary, Association for the Study of Failure, Aug 19, 2011, Japan. 